\title{
Effects of Dietary Protein Level on Growth Performance, Carcass Composition and Survival Rate of Fry Monosex Nile Tilapia, Oreochromis niloticus Reared under Re-circulating System
}

\author{
Abdoulaye Loum \\ Institut Universitaire de Pêche et d'Aquaculture (IUPA), Université Cheikh Anta Diop \\ UCAD II bâtiment pédagogique/Rez de chaussée, BP: 5005 DAKAR
}

Mariama Sagne

Institut Universitaire de Pêche et d'Aquaculture (IUPA), Université Cheikh Anta Diop

UCAD II bâtiment pédagogique/Rez de chaussée, BP: 5005 DAKAR

\section{Jean Fall (Corresponding author)}

Institut Universitaire de Pêche et d'Aquaculture (IUPA), Université Cheikh Anta Diop

UCAD II bâtiment pédagogique/Rez de chaussée, BP: 5005 DAKAR

Tel: 221-77-956-4339 E-mail: kagoshima77@yahoo.com

\begin{abstract}
Diegane Ndong
Agence Nationale de l'Aquaculture, Cité Comico 3 VDN Liberté 6 Extension LOT N1

BP: 1496 DAKAR
\end{abstract}

Malick Diouf

Institut Universitaire de Pêche et d'Aquaculture (IUPA), Université Cheikh Anta Diop

UCAD II bâtiment pédagogique/Rez de chaussée, BP: 5005 DAKAR 
Alassane Sarr

Institut Universitaire de Pêche et d'Aquaculture (IUPA), Université Cheikh Anta Diop

UCAD II bâtiment pédagogique/Rez de chaussée, BP: 5005 DAKAR

\title{
Omar Thiom Thiaw
}

Institut Universitaire de Pêche et d'Aquaculture (IUPA), Université Cheikh Anta Diop

UCAD II bâtiment pédagogique/Rez de chaussée, BP: 5005 DAKAR

Received: January 15, 2013 Accepted: February 2, 2013

doi:10.5296/jbls.v4i2.3043 URL: http://dx.doi.org/10.5296/jbls.v4i2.3043

\begin{abstract}
Fry monosex Nile tilapia (Oreochromis niloticus) were fed in five dietary protein levels $(21 \%$, $25 \%, 32 \% 37 \%$ and $45 \%$ ) to investigate casual effects on growth performance, carcass composition and survival rate. Tests were carried out in 10 glass tank $(50 \times 25 \times 40 \mathrm{~cm})$ containers $(50 \mathrm{~L})$ of reticulating system maintained at $30 \pm 1^{\circ} \mathrm{C}$. At the beginning of tests, one hundred tilapia fry were randomly divided into five different groups with two replicates. Diets were fed to duplicate groups of ten fry with an initial weight of $1.25 \pm 0.25 \mathrm{~g} /$ fish during 42 days. The results showed significant effects of dietary protein on growth performance of reared fish. Weight gain (WG) and Specific Growth Rate (SGR) increased significantly with increasing dietary protein levels between $32.38 \%$ and $37.63 \%$. However, $45.5 \%$ of crude protein showed less important increase in growth parameters. The best Feed Conversion Rate FCR (1.26) was noticed in diet containing 37.63\% of crude protein. Accordingly, higher survival rate (\%) was recorded in fish fed on diets containing 32.38 and $37.63 \%$. There was no significant difference in protein body content of tilapia fed on five diets as compared to the initial fish. Lipid body content increased significantly with high dietary protein levels from $21.88 \%$ to $45.50 \%$. The carcass crude lipid was recorded as higher $(9.4 \%)$ in the fry fed on diet containing $45.50 \%$ protein, followed by fish fed on diet having protein $21.88 \%$. From results, diet containing $37.63 \%$ crude protein appears to be more suitable for monosex Nile tilapia growth, in related experience conditions. In this line, it is recommended to feed monosex tilapia fry.
\end{abstract}

Keywords: Protein, tilapia, Oreochromis niloticus, Growth

\section{Introduction}

Aquaculture is nowadays developing in Senegal and has become an increasingly important 
source of animal protein. Tilapia, the most farmed species worldwide, is considered as the most semi-intensive cultivated freshwater fish in Senegal (NAA, 2012).

Feeding represent $40-60 \%$ of production costs in aquaculture, with protein sources accounting for significant proportion of such cost (Fotedar, 2004). It provides the essential and non-essential amino acids which are required for muscle formation and enzymatic function, on one hand, and also provides energy for maintenance, on the other hand (Yang et al., 2002). Excess protein in fish diet might be wasteful and make diet uselessly expensive (Ahmad, 2000).

One of major factors which limit economic success in any commercial farming of species is food requirement. As important dietary stuff, protein consisted of animals directly influences on the formulation of diets and therefore affects production's cost. A wide range of feeding habits from carnivorous to herbivorous animals has been suggested as one possible reason for the wide range in protein requirements among fish species. As the main and most expensive component of the diet, protein draws greater attention in nutrition requirement studies.

Protein (most expensive macronutrient) requirement for fish fry is high and ranges from 35\% to $56 \%$ (Jauncy \& Ross, 1982). Furthermore, dietary protein requirements decreased with the development size and age of fish (El-Sayed \& Teshima, 1991). Based on various studies general conclusion is made that tilapia fry of size $<1 \mathrm{~g}$ requires diet with $35-50 \%$ protein, while 1-5 g fish requires diet with 30-40\% protein and 5-25 g fish requires diet with $25-35 \%$ protein (Balarin \& Haller, 1982).

Fry feed generally contains higher level of protein because the latter and energy requirements are higher in the early stages of life. Protein content of fry feed for tilapia farming has not been standardized yet although some farms use food stuff having $40 \%$ protein. So, it is essential to recommend the appropriate protein level of fry feed for economic production of healthy fry and maximize its lifespan as well.

However, the present study has been undertaken to conduct experimentation with different protein level diets viz. $21 \%, 25 \%, 32 \% 37 \%$ and $45 \%$ protein of fry feed to determine growth performance and survival rate of tilapia fry at different protein levels.

The main objective of this trial was to determine the optimum protein level which is necessary for optimum growth of monosex Nile tilapia (Oreochromis niloticus) under re-circulating system.

\section{Materials and Methods}

\subsection{Culture Conditions}

Male sex-reversed tilapia fry (Oreochromis niloticus) of initial weight $1.25 \pm 0.25 \mathrm{~g}$ were collected from tilapia hatchery in Richard Toll, Saint Louis, Senegal. Fish were acclimated to experimental conditions for a two week period. During this period, they were fed on commercial diet as previously done at the above mentioned hatchery. To determine the initial body composition, 20 randomly selected fish were killed, filleted and stored at $-18^{\circ} \mathrm{C}$ for proximate analysis on a later stage (AOAC, 1990). At the beginning of the experiment, one 
hundred were randomly divided into five different groups with two replicates containing 10 fish in each of them. Fish were kept in 10 glass tank $(50 \mathrm{~cm} \times 25 \mathrm{~cm} \times 40 \mathrm{~cm})$ containers $(50 \mathrm{~L})$. Each aquarium was put in a re-circulating system maintained at $30 \pm 1{ }^{\circ} \mathrm{C}$. An air stone continuously aerated each aquarium. All aquaria were cleaned up every day in the morning and the afternoon by siphoning off accumulated waste materials. Fish were fed with $10 \%$ of body weight per day and gradually decreased to $4 \%$ each day. Each diet was fed twice a day at 08:00 (a.m.) and 17:00 (p.m.) for 42 days to duplicate groups of fish. Each group was weighed in the beginning and in each couple of weeks; the amount of diet fed was adjusted, accordingly. A photoperiod of $12 \mathrm{~h}$ light, $12 \mathrm{~h}$ dark (08:00-20:00h) was used. Fluorescent ceiling lights supplied the illumination. After 6 weeks of feeding or farming, concerned fish were taken out from each treatment, while the dorsal muscle tissue of each of them was dissected and used for body composition analysis.

\subsection{Diet Preparation}

Five diets were formulated to contain different levels of digestible protein and approximately equal amount of digestible energy. Out of the total dietary protein, $10 \%$ were from fish meal (FM, crude protein $58.71 \%$ ) and $90 \%$ from different ratios of maize meal and shrimp waste meal (crude protein $48.12 \%$ ) (Table1).

Table 1. Composition of experimental diets for tilapia (Oreochromis niloticus)

\begin{tabular}{|lccccc|}
\hline Ingredients & $21 \%$ & $25 \%$ & $32 \%$ & $37 \%$ & $45 \%$ \\
\hline Fish meal & 170 & 170 & 170 & 170 & 170 \\
\hline Maize meal & 578 & 432 & 285 & 138 & 7 \\
\hline Shrimp waste meal & 72 & 218 & 365 & 511 & 643 \\
\hline Cellulose & 100 & 100 & 100 & 100 & 100 \\
\hline Fish Oil & 20 & 20 & 20 & 20 & 20 \\
\hline Vegetable oil (PO + SO)* & 40 & 40 & 40 & 40 & 40 \\
\hline Vit mix $^{\mathrm{a}}$ & 10 & 10 & 10 & 10 & 10 \\
\hline Min mix $^{\mathrm{b}}$ & 10 & 10 & 10 & 10 & 10 \\
\hline
\end{tabular}

*PO : peanut oil

*SO: soybean oil

PO/ SO: ratio 1:1

Main protein sources (fishmeal, shrimp waste meal and maize meal) already grounded into mill were passed as particles through no. $40(425 \mu \mathrm{m})$ mesh sieve. Mineral mix and vitamin mix were purchased from Aquavet Company, Thiès, Senegal. After having thoroughly mixed ingredients, appropriate quantity of water (30\% for $100 \mathrm{~g}$ of mixed ingredients). At first feeds were formulated containing $21 \%, 25 \%, 32 \%, 37 \%$ and $45 \%$ protein from three ingredients such as fish meal, maize and shrimp waste meal. Formulation of feeds was done by Pearson's method. After formulation, feeds were prepared by mixing ingredients and a proximate analysis was realized. The protein levels of the prepared feeds were found $21.88 \%, 25.57 \%$, $32.38 \%, 37.63 \%$ and $45.50 \%$ (Table 2). Diets were supplemented with $6 \%$ of fish oil mixture (FO) and vegetable oil (VO). Dough was passed through an extruder to produce spaghetti and dried at $37^{\circ} \mathrm{C}$ for two days. The dried diet was packaged into plastic bag and stored frozen 
ready to be used. The proximate composition of the experimental diets and samples of the dorsal muscle was analyzed according to AOAC standard methods (1984).

Table 2. Proximate analysis of experimental diets fed tilapia (Oreochromis niloticus)

\begin{tabular}{|lccccc|}
\hline \multicolumn{7}{|c|}{ Treatments } \\
\hline Composition & $21 \%$ & $25 \%$ & $32 \%$ & $37 \%$ & $45 \%$ \\
\hline Dry matter * & 89.55 & 89.12 & 88.87 & 88.39 & 87.31 \\
\hline Crude Protein * & 21.88 & 25.57 & 32.38 & 38.63 & 45.5 \\
\hline Crude lipid * & 8.96 & 7.4 & 6.71 & 7.21 & 5.02 \\
\hline Crude fiber * & 4.9 & 6.4 & 3.57 & 7.04 & 9.42 \\
\hline Ash & 02 & 02.42 & 02.98 & 03.76 & 04.46 \\
\hline Energy $(\mathrm{cal} / \mathrm{kg})$ & 176.4 & 196.48 & 211.11 & 217.73 & 266.1 \\
\hline
\end{tabular}

*presented in percentage of dry weight

\subsection{Growth Parameters}

Growth response parameters were calculated as follows: weight gain (WG, g/ fish) $=$ final mean body weight - initial mean body weight; specific growth rate (SGR, \% /day) $=(($ In Wt- In Wi) /T) $\mathrm{x} 100$, where $\mathrm{Wt}$ is the weight of fish at time $\mathrm{t}, \mathrm{Wi}$ is the weight of fish at time 0 and $\mathrm{T}$ is the rearing period in days; feed conversion rate $(\mathrm{FCR})=$ total dry feed fed $\mathrm{g} /$ fish / total wet weight gain $\mathrm{g} /$ fish. Survival rate $(\%)=100$ (number of fish which survived/initial number of fish).

\subsection{Water Quality Measurement}

Water temperature and dissolved oxygen were measured every other day using YSI Model 58 oxygen meter (Yellow Springs Instrument, Yellow Springs, OH, USA).

\subsection{Statistical Analysis}

The data were analyzed using the statistic system (SAS-PC) (Joyner, 1985) and subjected to one-way analysis of variance (ANOVA). Treatment effects were considered significant at $\mathrm{P}<0.05$; Duncan's test was used to compare significant difference among the treatments.

\section{Results}

The water temperature monitored during the study period in the experimental aquarium was 29 to $31^{\circ} \mathrm{C}$, dissolved oxygen content in the present experiment ranged from 5 to $7 \mathrm{mg} / \mathrm{l}$. The Weight Gain (WG), Specific Growth Rate (SGR) and Feed Conversion Rate (FCR) for fry tilapia after the feeding trial are presented in Table 3. Dietary protein level significantly influenced the tilapia fry's growth and the best results were obtained with a dietary protein level of $32 \%$ and $37 \%$ in respect of weight gain, SGR and FCR as well as survival. So diet containing approximately $32 \%$ to $37 \%$ protein might be acceptable protein percentage for production of $O$. niloticus fry. The FCR in different treatments ranged from 1.26 to 1.91 . The best FCR (1.26) was observed in diet containing $37 \%$ of crude protein (Table 3 ). The survival rate of $O$. niloticus fry under different treatments ranged from 75 to $100 \%$ being $75 \%$ in fish fed on diet containing $21 \%, 90 \%$ in fish fed on diet containing $25 \%$ and $45 \%$. Significantly $(\mathrm{P}<0.05)$ higher survival rate $(100 \%)$ was recorded in the case of $32 \%$ and $37 \%$ (Table 3 ). Carcass composition data are presented in Table 4. There was no significant difference in protein body content of tilapia fed the five diets as compared to the initial fish. Lipid body 
content increased significantly $(\mathrm{P}<0.05)$ with increasing dietary protein levels from $21 \%$ to $45 \%$, but there was no-significant increase with the diet of $37 \%$ protein as compared to the initial fish. The carcass crude lipid was recorded as the highest $(9.4 \%)$ in the fry fed on diet containing $45 \%$ crude protein followed by fish fed on diet $21 \%$. There was no significant difference $(\mathrm{P}>0.05)$ in the carcass crude lipid of the fry fed on diet with $25 \%$ and $32 \%$ protein level.

Table 3. Initial, final weight, weight gain, SGR, FCR and survival of tilapia (Oreochromis niloticus)

\begin{tabular}{|lccccc|}
\hline \multicolumn{5}{c|}{ Treatments } \\
\hline Parameters & $21 \%$ & $25 \%$ & $32 \%$ & $37 \%$ & $45 \%$ \\
\hline Initial weight g/fish & 1.24 & 1.25 & 1.21 & 1.24 & 1.26 \\
\hline Final weight g/fish & 9.55 & 10.45 & 13.87 & 14.92 & 9.97 \\
\hline Weight gain g/fish & $8.31^{\mathrm{b}}$ & $9.21^{\mathrm{b}}$ & $12.66^{\mathrm{a}}$ & $13.68^{\mathrm{a}}$ & $8.71^{\mathrm{b}}$ \\
\hline Weight gain (\%) & $672.12^{\mathrm{b}}$ & $740.79^{\mathrm{b}}$ & $1050.79^{\mathrm{a}}$ & $1102.35^{\mathrm{a}}$ & $694.05^{\mathrm{b}}$ \\
\hline SGR & $1.66^{\mathrm{ab}}$ & $1.68^{\mathrm{ab}}$ & $1.39^{\mathrm{ab}}$ & $1.26^{\mathrm{a}}$ & $1.91^{\mathrm{b}}$ \\
\hline FCR & $4.84^{\mathrm{b}}$ & $5.07^{\mathrm{b}}$ & $5.82^{\mathrm{a}}$ & $5.92^{\mathrm{a}}$ & $4.93^{\mathrm{b}}$ \\
\hline Survival (\%) & 75 & 90 & 100 & 100 & 90 \\
\hline
\end{tabular}

${ }^{\mathrm{ab}}$ Means in the same column with the different letter are significantly different $(\mathrm{P}<0.05)$

Table 4. Proximate analysis of dorsal muscle of tilapia (Oreochromis niloticus)

\begin{tabular}{|lllllll|}
\hline Composition & Initial fish & $21 \%$ & $25 \%$ & $32 \%$ & $37 \%$ & $45 \%$ \\
\hline Protein (N x 6.25\%) & $18.38^{\mathrm{a}}$ & $19.69^{\mathrm{a}}$ & $18.81^{\mathrm{a}}$ & $19.88^{\mathrm{a}}$ & $18.75^{\mathrm{a}}$ & $20.12^{\mathrm{a}}$ \\
\hline Lipid (\%) & $3.4^{\mathrm{c}}$ & $7.4^{\mathrm{bc}}$ & $5.0^{\mathrm{ab}}$ & $4.2^{\mathrm{bc}}$ & $3.7^{\mathrm{c}}$ & $9.4^{\mathrm{a}}$ \\
\hline
\end{tabular}

${ }^{\text {abc }}$ Means in the same column with the different letter are significantly different $(\mathrm{P}<0.05)$

\section{Discussion}

The present study showed significant effects of dietary protein level on growth performance of fry monosex Nile tilapia. Weight gain and specific growth rate of fish were improved significantly with increasing dietary protein levels from $21 \%$ to $37 \%$. However, there was no significant increase in fish fed on diet containing $21 \%, 25 \%$ and $45 \%$ protein. The best results were obtained with a dietary protein level of $32 \%$ and $37 \%$ in respect of weight gain, SGR. This may be due to the increase in protein utilization and digestibility with the increase in dietary protein level up to $37 \%$. The decrease in WG and SGR at 45\% dietary protein level may be due to the decrease in protein utilization and digestibility above $37 \%$ dietary protein level. Many authors obtained conflicting results from their studies on tilapia nutrition. The dietary protein requirements of several species of tilapia have been estimated to range from $20 \%$ to 56\% (El-Sayed \& Teshima, 1992). Siddiqui et al., (1988) reported an optimum dietary requirement of $40 \%$ for $O$. niloticus fry (initial weight. $0.838 \mathrm{~g}$ ), and $30 \%$ for young fish (initial weight, 40g). Jauncey (1982a) and El-Sayed \& Teshima, (1992) also reported 40\% for fingerlings and fry respectively. Kaushik et al. (1995) observed the maximum growth rates and feed efficiency at 35\% dietary protein for the same species. Diyaware et al. (2009) revealed the best growth rate in hybrid catfish, Heterobranchus bidorsalis $\times$ Clarias anguillaris fry at $40 \%$ dietary crude protein level which also provided support to our finding. Sotolu (2010) who 
reported $40 \%$ dietary protein level resulted in efficient mean weight gain, specific growth rate and feed conversion ratio in C. gariepinus. Adewolu \& Adoti (2010) reported that fish fed continuously on high protein diets $(35 \%)$ resulted in significantly higher growth rate and feed utilization in C. gariepinus. Ahmad et al. (2012) reported that the highest growth rate in tilapia achieved in feed having $40 \%$ dietary protein level during the research period. The difference reported may be due to different protein sources used, various components, formulation methods, different environmental conditions, level of dietary intake and experimental duration.

In the present study, the best FCR was obtained with fish fed on diet containing 37\% protein, the poorest FCR was observed in fish fed on diet having $45 \%$ protein, but there was no significant difference between FCR obtained by 21, 25, 32\% protein diet. These results are in line with those of Wee \& Tuan, (1988) who reported that better FCR values were obtained with increasing dietary protein levels up to $42.5 \%$ and deteriorated slightly by diet containing $50 \%$ tilapia species.

The survival rate of $O$. niloticus fry under different treatments ranged from 75 to $100 \%$ being $75 \%$ in fry feed containing $21.88 \%$ proteins. Significantly $(\mathrm{P}<0.05)$ higher survival rate $(\%)$ was recorded in case of diet containing $32 \%$ and $37 \%$. Survival rate more than $80 \%$ is excellent in nursery operation (Sumi et al., 2011). Therefore from findings, it can be suggested that fry feed containing 32 to $37 \%$ proteins is suitable for tilapia fry rearing.

Ahmad et al (2012); Tidwell et al. (2005) and Pedro et al., (2001) reported the increase in carcass protein content with the increase in dietary protein level. In contrast, in the present study there was not any significant difference in protein body content of tilapia fed on five diets as compared to the initial fish. No relation between the dietary protein content and the carcass fat composition was observed. There was no defined trend identified in this study. This is in contrast with results reported by (Ahmad et al., 2012) who reported that carcass lipid content exhibited positive relationship with dietary lipid level in tilapia and in rainbow trout reported by (Yamamoto et al., 2000; Gumus \& Ikiz, 2009). Moreover, Attack et al. (1979); Chen \& Tsai, (1994) observed either linear or inverse relationships respectively.

Data for lipid content of the fish body in response to dietary levels could be divided into three groups. The first group refers to fish which carcass lipid content increased significantly $(\mathrm{P}<0.05)$ with increasing dietary protein levels from $21 \%$ to $45 \%$. The second group was composed of fish fed on diet of $37 \%$ protein that body lipid content did not show any significant increase as compared to initial fish. Conversely, the last group has lipid contents that decreased significantly with increasing dietary protein levels up to $30 \%$ crude protein (Bahnasawy, 2009). The carcass crude lipid was recorded as the highest $(9.4 \%)$ in the fry fed on feed $45 \%$ followed by fish fed on diet $21 \%$. The same observations have been reported by (Ahmad et al., 2012).

In conclusion, this study indicates that diet containing $37 \%$ crude proteins appears to be more suitable, economical and successful culture of the tilapia fry.

\section{Acknowledgement}

Authors of the aforementioned study would like to thank staff members of the National 
Aquaculture Agency (NAA) of Senegal for providing us with fish, vitamin mix and mineral mix as well. They would highly appreciate the assistance provided by Ecole Supérieure Polytechnique (ESP) and Ecole Nationale des Sciences Agronomiques (ENSA) laboratories staff members.

\section{Reference}

Adewolu, M. A., \& Adoti, A. J. (2010). Effect of mixed feeding of varying dietary protein levels on the growth and feed utilization of Clarias gariepinus fingerlings. Journal of Animal and Veterinary Advances, 9(10), 1415-1419. http://dx.doi.org/ 10.3923/javaa.2010.1415.1419

Ahmad, M. H. (2000). Improve productive performance in fish. Ph.D. Dissertation, Animal Prod. Department, Faculty of Agriculture, Zagazig University

Ahmad, M., Qureshi, T. A., Singh, A. B., Susan, M., Kamlesh, B., \& Salman, R. C. (2012). Effect of dietary protein, lipid and carbohydrate contents on growth, feed efficiency and carcass composition of Cyprinus carpio communis fingerlings. International Journal of Fisheries and Aquaculture, 4(3), 30-40. http://www.academicjournals.org/IJFA 10.5897/IJFA11.080

A. O. A. C. (1984). Official Methods of Analyses. 15th edition. In K. Helrich (ed.), Association of Official Analytical Chemists, Inc., Arlington, VA, USA.

Attack, T. H., Jauncey, K., \& Matty, A. J. (1979). The utilization of some single cell proteins by fingerlings mirror carp (Cyprinus carpio). Aquaculture, 18, 337-348. http://dx.doi.org/10.1016/0044-8486 (79)90037-1

Balarin, J. D., \& Halfer, R. D. (1982). The intensive culture of tilapia in tanks, raceways and cages: In J.F. Muir and R.J. Roberts (Eds.). Recent Advances in aquaculture. Crom Helm, London, pp: 265-356.

Bahnasawy, M. H. (2009). Effect of Dietary Protein Levels on Growth Performance and Body Composition of Monosex Nile Tilapia, Oreochromis niloticus L. Reared in Fertilized Tanks. Pakistan Journal of Nutrition, 8, 674-678. http://dx.doi.org/ 10.3923/pjn.2009.674.678

Chen, H. Y. \& Tsai, J. C. (1994). Optimal dietary protein level for growth of juvenile grouper, Epinephelus malabricus, fed semipurified diets. Aquaculture, 119, 265-271. http://dx.doi.org/10.1016/0044-8486 (94)90181-3

Diyaware, M. Y., Modu, B. M., Yakubu, U. P. (2009). Effect of dietary protein levels on growth performance and feed utilization of hybrid catfish, Heterobranchus bidorsalis $\times$ Clarias anguillaris. African Journal of Biotechnology, 8(16), 3954-3957. http://dx.doi.org/ 10.5897/AJB09.427

El-Sayed, A. M., \& Teshima, S. (1991). Tilapia nutrition in aquaculture. Reviews in Aquatic Sciences, 5, 24-265.

El-Sayed, A. M., \& Teshima, S. (1992). Protein and energy requirements of Nile tilapia, Oreochromis niloticus, fry. $\quad$ Aquaculture, 103, 55-63. 
http://dx.doi.org/10.1016/0044-8486(92)90278-S,

Fotedar, R. (2004). Effect of dietary protein and lipid source on the growth, survival, condition indices and body composition of marron, Cherax tenuimanus (Smith). Aquaculture, 230, 439-455. http://dx.doi.org/10.1016/S0044-8486 (03)00418-6

Gumus, E., Ikiz, R. (2009). Effect of dietary levels of lipid and carbohydrate on performance, chemical contents and digestibility in rainbow trout, Oncorhynchus mykiss. Pakisran. Veterinary Journal, 29(2), 59-63.

Jauncey, K. (1982a). The effect of varying dietary protein levels on the growth, food conversion, protein utilization and body composition of juvenile tilapias (Sarotherodon mossambicus). Aquaculture, 27, 43-54. http://dx.doi.org/10.1016/0044-8486 (82)90108-9

Jauncy, K., Ross, B. (1982). A guide to tilapia feed and feeding University of Stirling, Scotland, UK. 111pp.

Kaushik, S. J., Doudet, T., Médole, F., Aguirre, P., \& Blank, D. (1995). Protein and energy needs for maintenance and growth of Nile tilapia (Oreochromis niloticus). Journal of Applied. Ichthyology, 11, 290-296. http://dx.doi.org/ 10.1111/j.1439-0426.1995.tb00029.x

Pedro, N. D., Guijarro, A. I., Delgado, M. J., Patina, L. P., Pinillos, M. L., Bedate, M. A. (2001). Influence of dietary composition on growth and energy reserves in tench, Tincta ticta.
Journal
of
Applied
Ichthyology,
17 ,
25-29.

http://dx.doi.org/10.1046/j.1439-0426.2001.00274.x

Santiago, C. B., Banes-Aldaba M., \& Laron, M. A. (1982). Dietary crude protein requirement of Tilapia nilotic fry. Kalikasan philipp. Journal of Biology, 11, 255-265

Siddiqui, A. Q., Howlader, M. S., \& Adam, A. A. (1988). Effect of dietary protein levels on growth, feed conversion utilisation in fry and young Nile tilapia, Oreochromis niloticus. Aquaculture, 70, 63-73 http://dx.doi.org/10.1016/0044-8486 (88)90007-5,

Sotolu, A. O. (2010). Effect of varying dietary protein levels on the growth performance of Clarias gariepinus fry. Journal of Livestock Research for Rural Development, 22(4), 312-318

Sumi, K, R., Das, M., \& Siddika, I. ( 2011). Effect of different protein levels of fry feed on the production of quality tilapia (Oreochromis niloticus) fry. Journal Bangladesh Agriculture. University, 9(2), 365-374.

Tidwell, J. H., Coyle, S. D., Bright, L. A., \& Yasharian, D. (2005). Evaluation of plant and animal source proteins for replacement of fish meal in practical diets for the largemouth bass, Micropterus salmoides. Journal World Aquaculture Society, 36, 454-463 http://www.blackwell-synergy.com/doi/abs/10.1111/j.1749-7345.2005.tb00393.x

Wee, K. L., Tuan, N. A. (1988). Effects of dietary protein level on growth and reproduction in Nile tilapia (Oreochromis niloticus). ICLARM Conference Proceedings, 15, 623

Yamamoto, T., Unuma, T., Akiyama, T. (2000). The influence of dietary protein and fat levels on tissue free amino acid levels of fingerling rainbow trout (Oncorhynchus mykiss). Journal 


\section{Macrothink}

of Aquaculture, 182(3-4), 353-372 http://dx.doi.org/10.1016/S0044-8486 (99)00277-X

Yang, S. D., Liou, C. H., \& Liu, F. G. (2002). Effects of dietary protein level on growth performance, carcass composition and ammonia excretion in juvenile silver perch (Bidyanus bidyanus). Aquaculture, 213, 363-372. http://dx.doi.org/10.1016/S0044-8486 (02)00120-5

\section{Copyright Disclaimer}

Copyright reserved by the author(s).

This article is an open-access article distributed under the terms and conditions of the Creative Commons Attribution license (http://creativecommons.org/licenses/by/3.0/). 